\title{
To Whom Belongs the Land? Confrontation in Karabakh: On the Origin of the Albanian Arsacids Dynasty
}

\author{
Ramin Alizadeh" ${ }^{*}$, Tahmina Aslanova², Ilia Brondz ${ }^{3 \#}$ \\ ${ }^{1}$ Azerbaijan National Academy of Sciences (ANAS), Baku, Azerbaijan \\ ${ }^{2}$ Department of History of Azerbaijan, History Faculty, Baku State University (BSU), Baku, Azerbaijan \\ ${ }^{3}$ Norwegian Drug Control and Drug Discovery Institute (NDCDDI) AS, Ski, Norway \\ Email: ^raminalizadeh17@gmail.com, tehmineasl@gmail.com, ilia.brondz@gmail.com
}

How to cite this paper: Alizadeh, R., Aslanova, T., \& Brondz, I. (2021). To Whom Belongs the Land? Confrontation in Karabakh: On the Origin of the Albanian Arsacids Dynasty. Voice of the Publisher, 7, $32-43$.

https://doi.org/10.4236/vp.2021.71003

Received: December 6, 2020

Accepted: March 9, 2021

Published: March 12, 2021

Copyright $\odot 2021$ by author(s) and Scientific Research Publishing Inc. This work is licensed under the Creative Commons Attribution International License (CC BY 4.0).

http://creativecommons.org/licenses/by/4.0/

\begin{abstract}
The escalation of the Karabakh conflict during late 2020 and the resumption of the second Karabakh War-as a result of the provocative actions by the Armenian government and its puppet regime, the so-called "Artsakh Republic"-have aroused the renewed interest of the scientific community in the historical origins of the territory over which Azerbaijan and Armenia have been fighting for many years. There is no consensus among scientific experts on this conflict's causes or even its course, and the factual details and their interpretation remain under discussion. However, there are six resolutions by the United Nations Security Council that recognize the disputed territories as Azerbaijan's national territory. This paper presents the historical, linguistic, and juridical facts that support the claim of Azerbaijan to these territories. The second war in Nagorno-Karabakh is a national liberation war for Azerbaijan.
\end{abstract}

\section{Keywords}

Karabakh, Caucasus, Azerbaijan, Armenia, Arshakids, Arsak, Albania, National Liberation War

\section{Introduction}

The center of the conflict between Azerbaijan and Armenia is the southern Caucasus, which is formally part of Asia Minor and shares borders with the Middle East. The region is populated by several ancient tribes, which, around 5.000-4.000 B.C., had already formed the first-known fortified city of a centra-

"Project leader. 
lized kingdom, which expanded to become Urartu/Ararat. The names Urartu (Hebrew: אָרָָט), Ararat; Assyrian: māt Urarțu; (Schrader, 1885) The Cuneiform inscriptions and the Old Testament), Babylonian: Urashtu; and Armenian: nıpupunn,, are all names for this kingdom in different languages. The earliest mention of this place occurs in the Old Testament. The ruler of Assyria Shalmaneser I (1263-1234 B.C.) completed a campaign in which he subdued the entire territory of Uruatri (Horace Jr., 1937), (Zimansky, 1998). The Urartians were first mentioned in the $13^{\text {th }}$ century B.C. However, they are not currently in the Old Testament and nor is the Assyrian King Shalmaneser I have been mentioned the Armenians or tribes of Armenians. The early Urartian rulers named themselves the kings of Nairi. Nairi was already totally absorbed by Assyria in the 8th century B.C. (Zimansky, 1985). The Mannaeans/mə'ni:ənz/ (the country name is usually Mannea, or, in Akkadian, Mannai, and in Biblical Hebrew, Minni (מי), were an ancient people who lived in the territory of present-day northwestern Iran, south of lake Urmia, around the $10^{\text {th }}$ to $7^{\text {th }}$ centuries B.C. At that time, they were neighbors of the empires of Assyria and Urartu, as well as of other small buffer states between the two, such as Musasir and Zikirta. Territory refers to the Mannaeans as Minni (מני) (Holy Bible, King James Version, 2010, Jeremiah 51: 27). In the (The Jewish Encyclopedia, 1901), Minni is identified with Armenia, but it is the geographical not the ethnic name. Armenia is interpreted by some specialist scholars as Har Mani, that is, the "mountain region of Minni." In Hebrew, the meaning of "har" is mountain; for example, Har ha Carmel is the mountain of the Carmel (Haifa, Israel). According to examinations of the place and personal names found in Assyrian and Urartian texts, the Mannaeans, or at least their rulers, spoke Hurrian, a non-Semitic and non-Indo-European language related to Urartian, with no modern language connections (Richard, 1993). The native name of Armenia the country was Zujp (Hayk'); however, it is currently rarely used. The contemporary name is Zujuuuuuu (Hayastan) https://www.tripadvisor.com/LocationPhotoDirectLink-g8473191-d8471011-i40 0176096-National_Museum_of_Armenian_Ethnography_and_History_of_the_L iberation_S.html.

Armenians usually associate themselves with the ancient Urartians as their ancestors. However, Urartians spoke an "Urartian language". "Urartian language" is the name retroactively applied by historians and linguists to the extinct language used in the cuneiform inscriptions of the Kingdom of Urartu. Other names used to refer to the language are "Khaldian" ("Haldian"), or "neo-Hurrian". The Urartian language is an ergative-agglutinative language, which belongs to neither the Semitic nor the Indo-European language families (Diakonoff, 1992). Semitic, Khaldian ("Haldian") and neo-Hurrian languages are the autochthon languages of the region. Armenian ([haje'ren] hayeren) is an Indo-European language and is not an autochthon language in the southern Caucasus region, Asia Minor, or the Middle East. The carriers of a non-autochthon language cannot belong to the autochthon population. The most feasible hypothesis is that the Hayk people migrated from the Balkans (possibly from the Hellas region) to 
Anatolia together with, or at the same time as, the Phrygians (according to Herodotus, the Phrygians are an ancient Indo-European people, who dwelled in the southern Balkans). It is normal behavior for invaders to claim a territory by naming it after themselves. About 4000 years ago, the Israelite tribes invaded Canaan and named the territory as "the Land of Israel". Israelis have never hidden this fact. Juts invaded the territory of present-day Denmark, and the peninsula on which Denmark is located is still named Jutland. Likewise, the Normans invaded the shores of La Manche (the English Channel) in present-day France and the territory continues to bear the name of Normandy today. The Britons invaded the islands and territory presently known as Great Britain. Another more speculative behavior of invaders is to name themselves after the invaded territory to hide the fact of their invasion. About three decades ago, the Albanians occupied Kosovo, appearing there as a new ethnic group, the Kosovars. About seven decades ago, in the territory of Israel, a new ethnic group, the Palestinians, emerged, claiming rights to the territories of Gaza, Samaria, and Judea. The territory of ancient Israel and Judea was named Palestine by the Romans after the destruction of Kingdom Judea. Several thousand years ago, the Hayk people migrated to Anatolia and the Southern Caucasus apparently from the Balkans and settled in the region of Har Mani (the mountains of Minni). They adopted the ethnic name of Armenians. To support their claim to the territory, they asserted that King Tigranes II, also known as Tigranes the Great, was an Armenian. However, the Armenians did not mention that the mother of $\mathrm{Ti}$ granes II was a princess of the Alan people (who are of Turkic ethnicity) and his father was Artavasdes I, who was of Parthian or Iranian ethnicity. Thus, Tigranes was not of the same Hayk ethnicity as the Armenians. Moreover, at the time of Tigranes II, the Hayk people were a tiny minority within the population of Armenia.

One of the ancient centers of civilization in the Caucasus region was formed in the territory of Azerbaijan. Karabakh has a special place in the rich history and cultural heritage of the Azerbaijan nation. Historically, this territory has become the focal point for foreign actors and their activities on a wide range of issues. The massive resettlement of Armenians in Karabakh, Irevan (current Yerevan, the present capital of Armenia), Goyche, Nakhchevan, and Borchali at the beginning of 19th century by Empire of Russia (Tsarist Russia) was accompanied by a massacre of the Azerbaijani Turks and falsification of the historical facts, including the change/distortion of the ancient toponyms of the Karabakh region, including the Orsak/Ersak toponym, which refers to the old Turkic people and covers the mountainous part of Karabakh.

\subsection{Conflict in Karabakh}

Basically, the conflict has started with the Armenian intention to annex Arsak-the mountainous part of Karabakh to himself and the newly-formed so-called "Artsakh Republic" is just serving to their interest firstly to be internationally recognized as a legitim state and then to realize the plan of annexation, 
the fact that cannot be accepted by the official Azerbaijan and Azerbaijani people having their own historical and legal grounds over the territory. The polemics on the historical name of the territory that had been changed over times, to identify the location and its first inhabitants become a complicated question in its detail and continuing to be more dubious due to the distortion of many valuable material and written sources by the "ill-intentioned forces" for decades. The literature on the history of the Karabakh and the conflict is vast but of variable quality. Considering to have a wide diversity of researches but the lack of a proper investigation about the origin of Arsak toponym the authors of this article aim to explore the new facts about the history of Arsak Turks using a number of available archeological, numismatic and written sources. The Arshakids dynasty, which ruled the Albanian state which existed in the northern part of Azerbaijan, was a branch of the Parthian Arshakids. The mountainous part of Karabakh was called Arsak province during the reign of the Albanian-Arshakids dynasty in the III-VI centuries. Armenians later misrepresented the name of this region as "Artsakh". Owing to the fictional concept of some Armenian researchers, the name of this region derives from the name of the land of Urtehi which mentioned in the Urartian sources. Note that the rock inscriptions that found in the village of Lower Zaghalı in the south-eastern part of Gokche Lake gives information about the campaign made by Urartian king Sarduri II to the land of Urtehi at the end of 40s of VIII B.C. But the Armenian fictionary conception is proved to be unfounded by both the facts that mountainous part of Karabakh did not belong to the areas ruled by Urartian Kingdom and the name of Arsakh province was first mentioned during the rule of Alban-Arshakids dynasty.

\subsection{Origin of Arsak Toponym}

In the early middle ages Albanian state, one of the mountainous provinces to the west of Azerbaijan was called Arsak or Ersak. Some researchers mistakenly

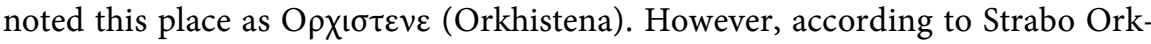
histena located in the Eastern Anatolia:

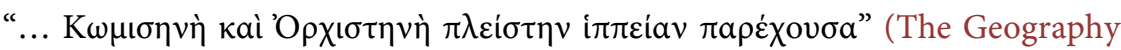
of Strabo, 1949). In some latin-language sources, the name of Lake Van mentioned as Lacus Archestiae, while in Syrian scripts there was given the name of Ercish (Argish) city by Lake Van (Piotrovskiy, 1944). This name is associated with Urartian ruler Argishti II who built Argishtikhinili fortress to the north of Lake Van. Armenian historians G.A. Kapansyan, N. Adons, N.V. Arutyunyan, A. Mnatsakanyan, B. Ulubabyan and O. Karagozyan by distorting Arsak as "Artsakh" associated it with Urte ("Urtechi") to the south-east of Lake Goyche that had been exposed to the attacks from Urartu in VIII century B.C. (Melikishvili, 1960), (Harutyunyan, 2001), (Harutyunyan, 2006), (Diakonoff \& Kashkai, 1981), (Salvini, Parmegiani, \& Dan, 2008), (Salvini, 2012), (Wartke, 1993) while both written and numismatic sources confirm incorrectness of the conception on emergence of Arsak toponym from Urtehi name. B. B. Piotrovski noted that an extension policy of Urartu to the north-east did not cover the moun- 
tainous part of Karabakh (Piotrovskiy, 1944). The toponym of Arsak was created in relation to the name of Arsak turkish dynasty that ruled Albanian state between III-VI centuries. The name of this dynasty comes from the name of the founder of Parthian state Arsak I. There were founded silver drahmas of Arsak I minted in Nisa city dated to III century B.C. on which were written in arami language "KKZN" and in ancient Greek "AR $\Sigma A K[O Y]$ ”, (“ARSAK[OY]" (see Figure 1). Since in arami there are not root words consisted of 4 consonants it can be considered as a loan-word. "KKZN" ("KKZ N") is read in Skythian-Sak Turkish as "kakanınız" ("kaganınız"). And speaking of to read correctly "AR $\Sigma \mathrm{AK}[\mathrm{OY}]$ " written in Greek on the money of Arsak I, this name should be read as "Orsaklar" because in Greek there is not a letter of " $\partial$ ". It is noteworthy that in old Greek "-OY” is mainly the plural masculine ending/suffix. The word of Orsak was written on principal sides of many Parthian coins whereas on the reverse the rulers were depicted with the bow and arrows in their hands that were also considered as the symbol of power between XI-XIII centuries in Great Seljug State and some other turkish states emerged after its collapse (Kucur, 2018), (Gülensoy, 1989), (Duran \& Baş, 2018). There were written in old greek "AYTOKPATOPO $\Sigma$ " on the coins of Arsak rulers relevant to emperor title (Abgarians, \& Sellwood, 1971). In Pahlavi scripts (Sasanian period) the names of Arsaks were given as “Ashkanis”. Strabo, a Greek geographer of I century B.C. wrote about the ethnic identity of Arsak I:

\section{In ancient Greek}

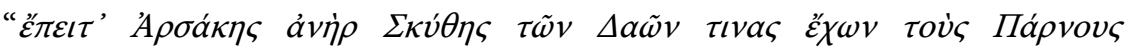

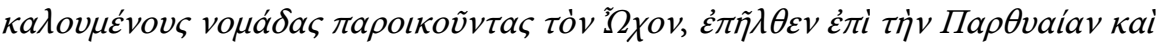

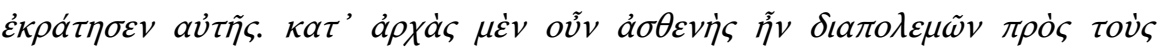

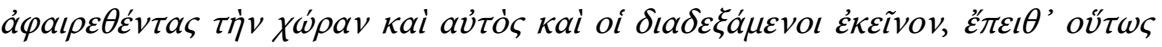

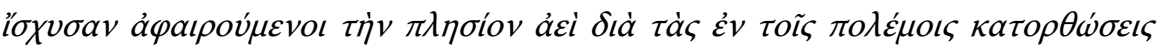

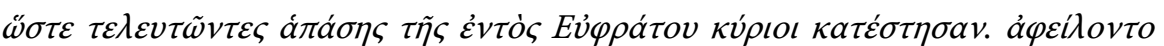

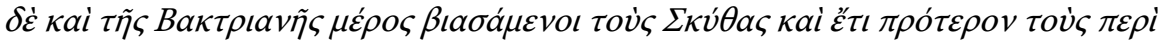

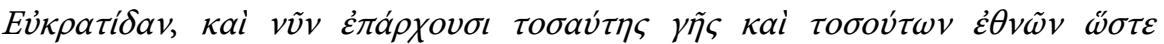

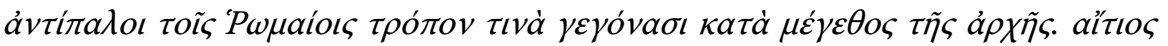

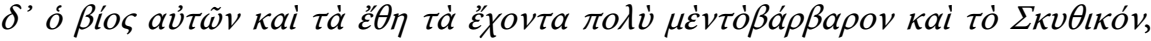

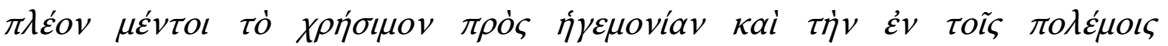
$\kappa \alpha \tau o ́ \rho \theta \omega \sigma \iota v$ ".

\section{In English:}

“... Arsaces, a Scythian, with some of the Däae (the Aparnians, as they were called, nomads who lived along the Ochus-R.A.), invaded Parthia and conquered it. Now at the outset Arsaces was weak, being continually at war with those who had been deprived by him of their territory, both he himself and his successors, but later they grew so strong, always taking the neighboring territory, through successes in warfare, that finally they established themselves as lords of the whole of the country inside the Euphrates. And they also took a part of Bactriana, having forced the Scythians, and still earlier Eucratides and his followers, to yield to them; and at the present time they rule over so much land and so 
Silver dracm of Arsaces I from Nisa (247-211 B.C.)
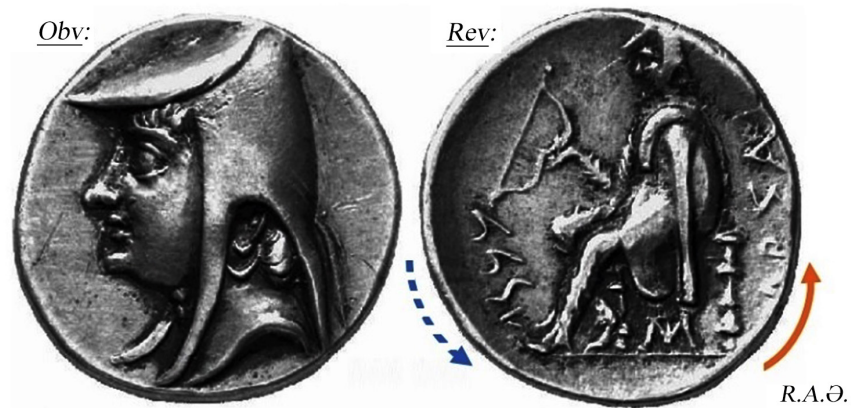

Obv: beardless head left, wearing bashlyk; circular border of pellets

Rev: beardless archer wearing bashlyk and cloak seated left on backless throne, holding bow in left hand; monogram MT below seat; circular border of pellets; below bow, single-line Aramaic inscription (KKZN);

behind archer, single-word Greek inscription read from outside $=$ APEAK[OY]

Figure 1. The silver drachm of Arsaces I from Nisa (247-211 B.C.).

many tribes that in the size of their empire they have become, in a way, rivals of the Romans. The cause of this is their mode of life, and also their customs, which contain much that is barbarian and Scythian in character, though more that is conducive to hegemony and success in war" (The Geography of Strabo. An English Translation, with Introduction and Notes, 2020).

Skythian warrior Arsak by taking Partava province in 247 B.C. laid a foundation of an independent Parthian State. And even more fascinating fact is Barda city became a capital of Alban state in the middle of V century namely in the ruling period of Vache II who belonged to Arsak dynasty. The initial name of Barda during Arsak dynasty was Partav. The first information about turkish origin of Arsak dynasty was given by a French orientalist A. J. Saint-Martin in his book published in 1850 in Paris, (Saint-Martin, 1850), the fragments on the history of Arshakids (Saint-Martin, 2011) (Fragments D' une Histoire Des Arsacides ed. By J.b.f. Lajard. (French Edition). In his work by referring to sources Skythian-Saks were called Turans, and their country Turan (Saint-Martin, 1850). It is proved that some toponyms were seriously distorted in the Armenian sources of early middle ages, so to give $\boldsymbol{O} \boldsymbol{r} \boldsymbol{s} \boldsymbol{a} \boldsymbol{k} / \boldsymbol{A} \boldsymbol{r} \boldsymbol{s}$ a $\boldsymbol{k}$ in those sources as "Artsakh" is the bright example of such falsifications while Moses Khorenatsi, the father of "Armenian history" wrote that Arshak (Arsak, Orsak) is the Parthian originated word (Khorenatsi, 1893).

\subsection{The Toponyms/Ethnonyms Related to Arsak}

According to a renowned researcher on history of Ancient East in the middle of VII century B.C. the northern borders of Median Empire crossed from the north of Araz/Arax river- "through the territory of former Skythian state" (Diakonoff, 1956). He explains the meaning of Sakasena related to this territory as "a dwelling/a living area of Saks" (in Persian languages "Saka-sayana") (Diakonoff, 1956). The discovering of many archeological findings belonged to Skythian-Sak people in Eastern Anatolia and Azerbaijan prove their enormous military-political power in the region. The name of Skolati given in ancient Greek 
scripts actually derives from the word "elats of sak" ("elats"- the people who engaged in cattle-breeding) in the old turkish language. In the Urartian sources old Turkish tribal unions (kinships) are referred to as Ishgigulu, in Assyrian-Ashguz or Ishguz, Ashkenaz-in the old-Jews religious scripts, in Persian-language sources-Sak, and in Greece and Latin sources-Skyth (skutai) and Skolati. The founder of Eren Turkish dynasty Eren I who first ended Urartu, then Mada's power in Eastern Anatolia in the sources is mentioned as "son of Sak" while in some manuscripts it was distorted as "Orontids". Armenians later by falsifying this dynasty which genetically was alien to them at all called it as "Yervantids". At the time of foundation of Ahamanid State by Cyrus II in VI century of B.C. Eren I ruled Eastern Anatolia. Armenian historian Simon Payaslian in his book "The history of Armenia: From the Origins to the Present" (2007) writes: Even the origin of Yervanduni (Orontid) family is not clear, some historians consider that they had close relations with Ahamanid Persian dynasty (Payaslian, 2007). This position of Payaslian confirms two facts, firstly, that he himself did not properly make an investigation on this question and secondly, the non-Armenian origin of this dynasty. There are lots of information given in the ancient manuscripts about the dwelling of Skythian-Sak tribes in the north part of Azerbaijan. Strabo in his work explains the formation of Sakasena name in connection with the name of the Sak tribe (The Geography of Strabo. An English Translation, with Introduction and Notes, 2020). According to Herodot and Pliny the Elder Skythians were called Sak by Persians (Herodotus, 1920), (Pliny, the Elder, 1961). In Pliny's "Natural History" dated to I century Sakasena covered a vast territory to the south from Kur river (Pliny, the Elder, 1961). He argues that the lifestyle, culture and customs of the people of 11 provinces out of 18 attached to Parthian Empire are similar with Skythian tribes (Pliny, the Elder, 1961). A Greek historian Arrian, an author of "The Anabasis of Alexander" which contains the description of attacks made by Alexander Macedonian to the East in order to differ the Sak ethnos of South Caucasus from the Skythian-Sak tribes living along the eastern shores of Caspian Sea and around of Lake Aral called them "sakasens", in meaning "People of Sakasena" (people of Sak land). Some researchers explain a meaning of sakasen word as "alike to sak". Arrian

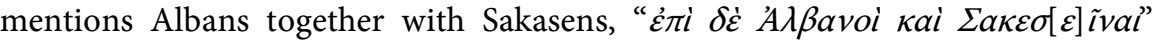
(Arrian, 1929) that proves their habitats to be close to each other. The turkic Sak ethnos mainly spread from the Eastern Anatolia to the area of confluence of Kur and Araz Rivers-to the Plain Sak which is known under the name of Balasakan and covers the lowland Karabakh-Mil Plain of Azerbaijan. Arrian also writes about the joint participation of Madas, kadusis, albans and sakasens in the battle

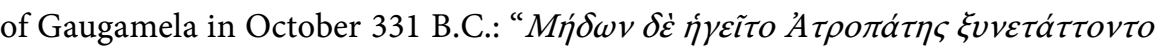

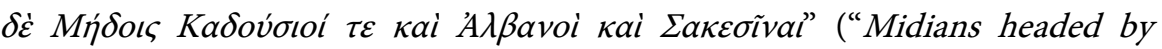
Atropat, kadusis, albans and sakasens were with them.") (Arrian, 1929). This evidence also supports a point of view that albans and sakasens lived in an area close to each other. 


\subsection{Albanian State of Azerbaijan and Its Relationship with Skythian-Sak Tribes: The Rule of Arsak Dynasty}

It is known that after the decline of Ahamanids dynasty its territory included

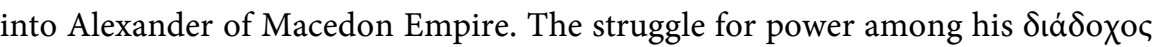
(diadochos-heirs) following the death of Alexander the Great caused the strengthening of Turkic people, and the reviving of the old statehood traditions. Skythian-Sak Turkic tribes also played an important role in the restoring of statehood traditions both in South Caucasus and Eastern Anatolia. The facts such as Sakasena was known as the country of Sak turks, Orsak/Arsak turkish dynasty's rule encompassed very huge territory from Central Asia to Syria, from Caucasus mountains to the Persian Gulf had been reflected in the written sources as well, additionally, the foundation and governance of Albanian state Figure 2, as M. Kalankatli (in Alban Tarihi; Son Hunlar Hazarlar Ermeniler Terekemeler,

https://www.garantikitap.com/kitap/alban-tarihi-son-hunlar-hazarlar-ermeniler -terekemeler-kalankatli-moses-9789758839407) mentioned, related to Skythian-Sak turkic ethnos. "Alban"-originates from the word of "alp", in old Turkish means brave, manful ("ərən", "ər"). The information that Alban state ruled by ["ərən"lər] ("Brave men") from Sysak tribe given in "The history of Albania" and Armenian sources support this fact as well. The name of Sak turkic ethnos has been given in Armenian-language sources as Sysak. This word consists of 2 parts-in armenian "si (se)", means "black" (in old turkish means big, huge), and "Sak" ethnonym, the general name given to turkish tribes by persians. The states founded in Azerbaijan and Eastern Anatolian lands were ruled by alps and erens (ərənlər) from Skyth-Sak turkish tribes in ancient period. The Eastern Anatolian territory that have been presenting by most Armenian scholars as fictitious Armenia was under the rule of Orsak/Arsak dynasty. There was not any territorial subject of Armenians even in the middle ages which they could cherish as their "motherland". According to the Armenian nationalist M. C. Gabrielyan's records in the beginning of XX century, Armenians lived as an ethnic minority under the turkish dynasties that were in power in Azerbaijan (Gabrielian, 1918). All said facts reconfirm that Armenians were not indigenous people of neither Eastern Anatolia nor the neighboring regions and they did not have any ancient state on spoken area.

Alban state in the northern and Adurbadagan in the southern parts of Azerbaijan were ruled by Arsak dynasty until the last king of Parthia Ardavan V was defeated by Ardashir I from Sasanian Persian dynasty in the Battle of Hormuzgan in April 224. It is much more relevant to call the branch of Arsak dynasty that was in the charge of Eastern Anatolia as Anatolian Arsak dynasty (Anatolian Arshakids). Some Armenian authors while speaking about Anatolian Arshakids wrongly mention them as "Armenian kings". In fact, there was not existed any independent state in Eastern Anatolia likewise in South Caucasus region related to neither hays nor Armenian community. In the Sasanian scripts of 


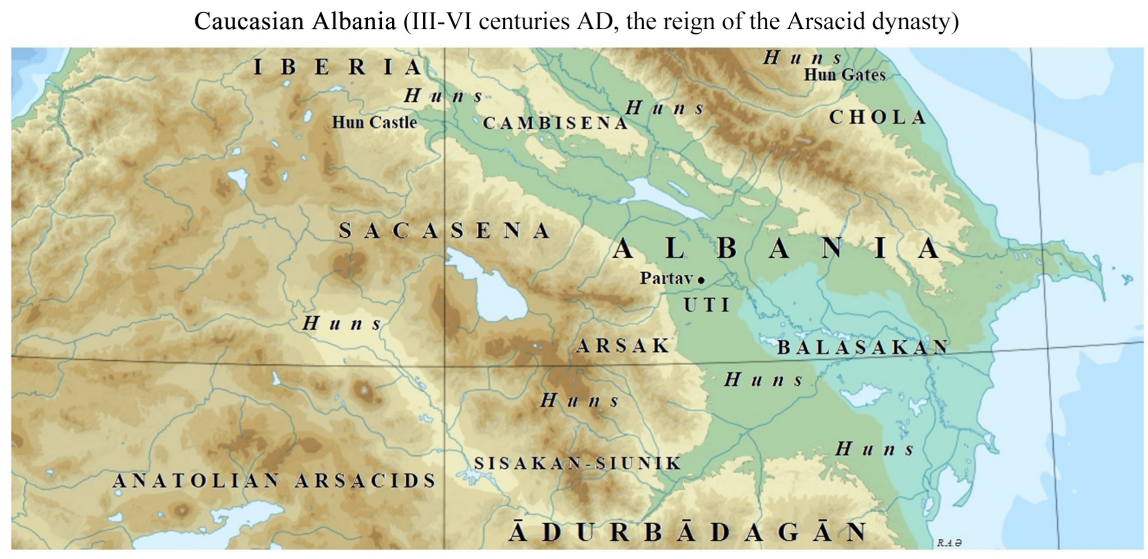

Figure 2. Caucasian Albania (III-VI century A.D.).

the second half of III century have been spoken about Sakan and Balasakan countries the same as Alban, Adurbadagan (Atropatena) and Iberia (Lukonin, 1987), (Kasumova, 1993). According to Albanian historian M. Kalankatli and Armenian historian M. Khorenatsi in the 1st century Albanian state covered vast mountainous and lowlands stretched in the south from Araz river to Hunan fortress in the north and was ruled by Eren and his courageous successors from Great Sak people (Lang, 1961; Khorenatsi, 1893). In the last II century B.C. there were minted silver coins with " $A$ " monogram of Parthian (Orsak/Arsak) rulers in the southern part of Azerbaijan and were known as "Arsak coins". Albanian historian Kirakos Ganjali and Byzantine historian L. Dyakon in their "History" spoke of the turkic tribes to be known under the name of Skythian in XI-XIII centuries likewise they were called in ancient period (Gandzaketsi, 1976), (Diakon, 1988). Since the beginning of XVIII century the members of Armenian mekhitarist (Mkhitar) trends who converted to Catholicism by contributing to the extension of anti-turk propaganda in Europe distorted the sources in grabar language and began to publish them in Venice. The works of Moses Khorenatsi, Lazar Parpetsi, Yeghishe, Koryun and other authors were distorted and published as "Hayots Patmutyun" (History of Hays) by mekhitarists which in due course began to be propagated in European countries under the name of "History of Armenia". The true history of oguzs, gipchags and Turkish tribal unions in such falsified works had been wiped out. Afterwards, the name of Orsak (Arsak) in its distorted form of "Artsakh" through these publications was included into academic periodicals as well. On the inscription of Ganjasar temple which was the hub of Albanian apostolic church in the middle ages Albanian-Khachin prince Hasan Jalal was mentioned as "the King of High and Big Arsak country, a grandson of Great Hasan, a Tsar of Albanian province, a son of Vakhtang tegi". This inscription once again affirms the fact of his ancestors to be from the old Arsak turkic ethnos. It is not by chance that Albanian christian melikids living in the mountainous part of Karabakh in their letters to Peter I and Catherine II listed themselves not as Armenians but Albans. These letters had been falsified by Armenian scholars and "Alban turks" replaced with "Agvan muslims" while 
"Arshaki generation" changed to "Armenian leaders' generation". The toponyms such as Sakasena, Balasakan (Plain Sak), Maskut (Massaget) that were mentioned in the ancient written inscriptions, current Sheki, Zaqatala toponyms, Sisakan district in Zengezur and the names of Sheki villages have arisen from the name of Sak turks. One of the turkic-originated inhabitants of Gozeldere village in Loru-Pembek territory was known as Arsaks (Đrsaklılar).

\section{Conclusion}

Thus, the archeological findings in the mountainous part of Karabakh and the written sources on the ancient history of this territory confirm invalidity of the faked conception about the formation of Arsak toponym from the toponym of Urtehi which covered the south-east part of Lake Goyche. The facts such as both the South Caucasus region and the part of Eastern Anatolia were within Skythian (Ishguz/Iskit) state in the middle of I millenium B.C., to be called as Sakasena of this territory in the sources of antique period after the declining of Skythian state had been also reflected in the scientifically valuable written sources. To name the mountainous part of Karabakh as Orsak/Arsak coincided with the ruling period of Arsak turkish dynasty in Albanian state. The facts that the name of the founder of this dynasty and Parthian Empire Arsak I was written on the contemporary silver coins as "Kaganiniz Arsak/Orsak" ("your Kagan Arsak"), his approved Skythian origin in the ancient scripts, the bow and arrow to be the symbol of power of Arsaks like it was in other turkish tribes, to be named as turans who were in war with persians indicate the turkish origin of Arsak toponym.

\section{Acknowledgements}

Authors are grateful to Norwegian Drug Control and Drug Discovery Institute (NDCDDI) AS, Ski, Norway for financial support.

\section{Conflicts of Interest}

The authors declare no conflicts of interest regarding the publication of this paper.

\section{References}

Abgarians, M. T., \& Sellwood, D. G. (1971). A Hoard of Early Parthian Drachms. The Numismatic Chronicle, (1966-) Seventh Series, 11, 103-119. https://www.jstor.org/stable/42664546

Arrian (1929). With an English Translation by Robson, E. I. Anabasis Alexandri (Books I-IV), Vol. I.

Diakon, L. (1988). Диакон, Л. (1988) История. Перевод Копыленко, М. М., Москва, II, S2, III, S7, VI, S11-13. https://www.twirpx.com/file/907994

Diakonoff, I. M. (1956). In: История Мидии от древнейших времен до конца в. до н. э., Москва-Ленинград, стр. 339.

Diakonoff, I. M. (1992). First Evidence of the Proto-Armenian Language in Eastern Ana- 
tolia. Annual of Armenian Linguistics, 13, 51-54.

Diakonoff, I. M., \& Kashkai, S. M. (1981). Repertoire Geographique Des Textes Cuneiformes Band 9: Geographical Names According to Urartian Texts.

Duran, R., \& Baş, A. (2018). Oğuzların Kayı boyu damgasının Anadolu Türk mimari süslemesinde motif olarak kullanılması üzerine. Selçuk Üniversitesi Türkiyat Araştırmaları Dergisi, 43, 525.

Gabrielian, M. C. (1918). Armenia, a Martyr Nation: A Historical Sketch of the Armenian People from Traditional Times to the Present Tragic Days (pp. 126-127). New York: Fleming H. Revell.

Gandzaketsi, K. (1976). History of Armenia (Translation from Ancient Armenian). (Гандзакеци, К. (1976) История Армении. Перевод с древнеармянского, предисловие и комментарий Ханларян, Л. А. Москва, I, §83).

Gülensoy, T. (1989) Orhun'dan Anadolu'ya Türk Damgaları, Damgalar, Imler, Enler. Ístanbul (pp. 62-65).

Harutyunyan, N. V. (2001). The Corpus of Urartian Cuneiform Inscriptions (pp. 250, 265). Yerevan: NAS RA. (Арутюнян, H. B. (2001) Корпус урартских клинообразных надписей. Ереван, Гитутюн, НАН РА, 250, 265).

Harutyunyan, N. V. (2006). Арутюнян, Н. В. Биайнили-Урарту. Военно-политическая история и вопросы топонимики. $2^{e}$ изд., доп. и перераб. СПб: Изд-во СПбГУ; Филол. ф-т СПбГУ. 2006. 368 с. ISBN 5-8465-0133-8 (Филол. ф-т СПбГУ) ISBN 5-288-03952-6 (Изд-во СПбГУ).

http://kronk.spb.ru/library/arutyunyan-nv-2006.htm

Herodotus (1920). With an English Translation by Godley, A.D (VII, 64.2). Cambridge, MA: Harvard University Press, London: W. Heinemann.

Holy Bible, King James Version (2010). Zondervan. The Gideons International, in the British Isles, Lutterworth, England.

Horace Jr., A. R. (1937). A Note on the Names Armânum and Urartu. Journal of the American Oriental Society, 57, 416-418. https://doi.org/10.2307/594522

Kasumova, S. Yu. (1993). Azerbaijan in the 3rd-7th Centuries, Baku. https://www.libex.ru/detail/book687359.html

Khorenatsi, М. (1893). Хоренский, М. (1893) История Армении, Перевод Эмина, H.О. Москва, типография Гатцук, В.А. II, \$9, стр. 62, \$11, стр. 63, \$68, стр.115.

Kucur, S. S. (2018). Selçuklu'nun İktidar Alameti Sikkeler/Derin Tarih. Özel Sayı, 12, 101-102.

Lang, D. M. (1961). The History of the Caucasian Albanians by Movses Dasxuranci (Translated by Dowsett, C.J.F.). London Oriental Series, Vol. VIII, London: Oxford University Press.

Lukonin, V. G. (1987). Луконин, В. Г. (1987) Древний и раннесредневековый Иран, 218-219, Москва.

Melikishvili, G. A. (1960). Urartian Cuneiform Inscriptions (pp. 161, 310). Moscow: Academy of Sciences of USSR. (Меликишвили, Г. А. (1960). Урартские клинообразные надписи. Москва: АН СССР (pp. 161, 310)

http://kronk.spb.ru/library/melikishvili-ga-1960.htm

Payaslian, S. (2007). The History of Armenia from the Origins to the Present. New York: Palgrave Macmillan.

Piotrovskiy, B. B. (1944). History and Culture of Urartu (p. 30). Yerevan: National Academy of Sciences of Armenia (NAS RA). (Пиотровский, Б. Б. (1944). История и культура. Урарту: Ереван, АН АССР) (In Russian) 
Pliny, the Elder (1961). Natural History, with an English Translation by Rackham, H. $S$ Jones, H. W. S. Vol: II. Cambridge, MA: Harvard University Press.

Richard, N. (1993). Iranian Identity in Ancient Times. Frye Iranian Studies, 26, 143-146. https://doi.org/10.1080/00210869308701792

Saint-Martin, A. J. (2011). Fragments D’une Histoire Des Arsacides. Charleston: Nabu Press.

Saint-Martin, M. J. (1850). Fragments d'une histoire des Arsacides (pp. 14-44). Paris: Imprimerie Nationale.

Salvini, M. (2012). Das Corpus der urartäischen Inschriften. Acta Iranica, 51, 117-129.

Salvini, M., Parmegiani, N., \& Dan, R. (2008). Corpus dei testi urartei: Le iscrizioni su pietra e roccia (Vol. I, p. 434). CNR, Istituto di studi sulle civilta dell'egeo e del vicino oriente; Paris, Diff. de Boccard.

Schrader, E. (1885). The Cuneiform Inscriptions and the Old Testament, Volume 1. London, Edinburgh: Williams \& Norgate.

The Geography of Strabo (1949). (English Translation by Horage, L.J., Cornell University) (Book XI, 14, 4, 321-314). Cambridge, MA: Harvard University Press. https://ryanfb.github.io/loebolus-data/L211.pdf

The Geography of Strabo (2020). An English Translation, with Introduction and Notes (Translated by Roller, D.W.). Cambridge: Cambridge University Press.

The Jewish Encyclopedia (1901). A Descriptive Record of the History, Religion, Literature, and Customs of the Jewish People from the Earliest Times to the Present Day. New York, London: Funk \& Wagnalls Company. https://archive.org/details/b29000488_0001/page/n11/mode/2up

Wartke, R. B. (1993). Urartu, das Reich am Ararat (Kulturgeschichte der antiken Welt), (German Edition) 59, P. von Zabern.

Zimansky, P. E. (1985). Ecology and Empire: The Structure of the Urartian State. Studies in Ancient Oriental Civilization, No. 41, Chicago, IL: Oriental Institute.

Zimansky, P. E. (1998). Ancient Ararat: A Handbook of Urartian Studies (p. 28). Delmar, NY: Caravan Books. 